\title{
The Relevance of Bandung Spirit in the Contemporary Global Trade
}

\section{Order}

\author{
Rio Nurhasdy, Rizki Rahmadini Nurika, Septian Nur Yekti* \\ rnurhasdy@yahoo.com,rr_nurika@yahoo.com,dyahwakil1@gmail.com
}

\begin{abstract}
Abstrak
Konferensi Bandung sudahdiadakan 60 tahun yang lalu. Kolonisasi telah resmi menghilang, Perang Dingin telah berakhir, dan Gerakan Non-Blok telah hampir kehilangan raison d'etre. Namun, sistem serupa dominasi kekuatan dalam tatanan dunia masih bertahan, perang terus mengancam kemanusiaan, dan kelaparan massal, penyakit, dan kemiskinan masih menjadi ciri sebagian besar negara di dunia. Ketidakadilan telah muncul dalam bentuk yang lebih canggih dengan dimensi yang lebih besar seperti sosial, hukum, dan ekonomi. Sebuah sistem dominasi dalam tatanan dunia dan ketidakadilan saat ini dapat ditemukan dalam konteks perdagangan global. Rezim dipelopori oleh Organisasi Perdagangan Dunia (WTO) sebagai tatanan baru telah meliberalisasi belahan dunia dengan menawarkan beberapa fungsi dan tujuan bermanfaat bagi negara, baik Utara dan Selatan. Bahkan, perintah ini tidak selalu membawa manfaat bagi mereka, terutama untuk negara-negara kurang berkembang yang sebagian besar berasal dari Selatan. Mereka dieksploitasi dan hanya mendapatkan sedikit manfaat dari liberalisasi perdagangan sementara negara-negara maju menuai banyak manfaat. Sebagai respon terhadap dunia kontemporer, makalah ini mencoba untuk menganalisis rasa perlunya Bandung Spiritsebagai wujud kehadiran postkolonial asli dan masa depan untuk Selatan. Pertanyaan mendasarnya adalah mengapa sistem dominasi masih ada hingga sekarang, di mana kekuasaan hegemonik dalam sistem perdagangan ditempati oleh Utara. Makalah ini juga mempertanyakan bagaimana Bandung Spriti perlu ditafsirkan karena tidak semua norma dan nilai-nilai yang ada di dalam Bandung Spirit bisa memungkinkan Selatan untuk memecahkan masalah global, terutama untuk isu-isu perdagangan
\end{abstract}

Kata Kunci: bandung spirit, liberalisasi perdagangan, selatan, WTO

\begin{abstract}
It has been 60 years after the Bandung Conference. Colonization has officially disappeared, the Cold War has ended, and the Non-Aligned Movement has almost lost its raison d'être. However, similar systems of domination by the powerful in the world order still persist, wars continue to threaten humanity, and mass hunger, diseases, and poverty still characterize many parts of the world. Injustice has appeared in more sophisticated forms and larger dimensions such social, law, and economy. A system of domination in the world order and injustice today can be found in the global trade context. The regime pioneered by the World Trade Organization (WTO) as a new order has liberalized parts of the world by offering some beneficial functions and objectives for countries, both North and South. In fact, this order doesn't always bring benefits for them, especially for less developed countries which mostly come from South. They were exploited and only get little benefits from trade liberalization while developed countries reap many benefits. As a response to the contemporary world, this paper attempts to analyze the sense of the necessity of Bandung Spirit for a genuine postcolonial present and future for South. This paper questions why system of domination still exists today, where hegemonic power in trading system is occupied by North. This paper also questions how the Bandung Spirit needs to be interpreted today because not all norms
\end{abstract}

${ }^{*}$ Correspondency : Septian Nur Yekti, RT 05 RW 06 Kedungrejo, Ds. Krowe, Kec. Lembeyan, Kab. Magetan, Jawa Timur.. Phone 085645730297 
and values lies within the Bandung Spirit could enable South to solve global problem, especially for trade issues.

Keywords: bandung spirit, trade liberalization, south, WTO

\section{Introduction}

Post WW II, 1955 period has been a critical moment when colonial powers were declined. The moment when movement for independence emerged among colonized country, especially from Western European: United Kingdom, France, and the Netherlands which at that moment increasingly untenable. A new "strategic part activity, which has revived the spirit of the 1955 efforts by partnership" uniting the newly independent nations of Asia and Africa. Such an alliance behind principles of global cooperation for development that led by President Soekarno, the Founding Father of the republic of Indonesia.

The Bandung Conference which held at 1955, prominently called as the AsiaAfrica Conference, formed midst of political uncertainty between the First and Second world country. Nuanced the cold war situation that emerged post-WWII, ushered in both a wave of bipolarity in international system either West or Soviet bloc.

Emphasized Bandung as seminal moment, in the political formation which notably known as pioneer in Non-Aligned Movement, Bandung Conference was a responds toward these blocs. With initiatives and leadership from Indonesia, Burma, Ceylon, India, Pakistan, and the Philippines, the conference has attracted by the leaders of twenty-nine formerly colonized. These newly independent nations of Asia and Africa were tried to seek one answer, an alternative from world order which dominated by the superpower, between West and Soviet. Later, Sauvy, France demographer called the 'outside of these blocs' as Third World.

The world order has changed, the regimes where First world dominating other countries has fading. Third world has succeeded in triggering solidarity movement among Africa and Asia nations, and it has sowed the seeds for revisioning international society in two further ways: equitable representation in international decision-making for newly independent states to take seriously in management of world affair. The spirit of the conference itself was motivated by the same history background of almost all the member states of the conference. They were 
colonialized by the western countries and their fate was determined by the force and the decicion made by western countries. Refering to the statement of the former Indoesian President, Soekarno, on the conference, this meeting was the form of the power raise of South countries which previousely tolerated decicions made by North countries that placed their own interest above all else. Consequently, South countries lived in poverty and humiliation (Zang, 1997) Essentially the changes has articulated an alternative set of principles for inter-state engagement which emphasized dialogue, collective problem-solving and search for consensus or compromise, and necessary alternative to the power politics and coercion that had been the basis of colonialism and that threatened to dominate international relation in a world of superpower block politics. Therefore, Bandung conference was a signal of Third World movement which mostly emphasis on political matters at the first time.

However, although political matter has been major issue in the conference, where Bandung participant were seek a recognition in international, economics issues seems also engaged by the Third World. The economic issue was stipulated by A 12point Economic Cooperation agenda as part of Final Communiqué' which acknowledge that economic development was an urgent priority for each states. Therefore, it affirmed the importance of economic cooperation besides political recognition.

As the secondary issue, economic matter such trade and economic cooperation still perceived hesitantly by Bandung participant because the countries still need needs of technical aid and assistance from outside African-Asian region, although the conference has give a great optimism for economic independence. Moreover, due the concept of economic independence (or free from West help) still nuanced as utopia, rather than look at the idea of economic independence, it seems the conference is trying to glorify independence to make a national policy because post colonial circumstances where no policy is free from imperialist.

In this stages, the notably known 'Bandung Spirit' is brings the idea of 'sovereignty' which try to exempt in policy decision making is free from any intervention. However, from the conference communiqué the delegates in conference seems choose to avoid issue that they felt had significant political overtones in case due dependency in their economy with First and Second World. 
presumably, the Conference did not degenerate into a forum for confrontation with the western world due African-Asian nations mostly were not in the economic takeoff stages, rather than those issue enduring west power in decisions making in each nation was priority. Bandung Spirit covers issues dealt by the two regions formulated in ten principles. They covers respect for fundamental human ringhts, respect for souvereignty and territorial integrity, equality of all nations large and small, nonintervention and non-interference in international affairs of another country. Besides it also covers peaceful settlement of disputes, promotion of mutual interest and cooperation, respect for justice and international obligations (Marsudi,2015).

By seeing the circumstances which occur at that present, the conference which generating Bandung Spirit, cannot makes cooperation in both African-Asian nation immediately happen. But, it already gives each nation the idea to not to rely to outside African-Asian nation. In couple years ahead South-South cooperation which comes from Bandung Spirit embryo has emerged as manifestation in realizing independence in economic related matter.

To conclude, Bandung Spirit tend to (or has) evolved to something bigger than political issue matter but it was a trigger to bigger cooperation between AfricanAsian nations. However, due to international relation back then, when formerly colonized nation gathered, give birth to Non-Alignment Movement as alternatives, it was a commendable movement and greatly appreciated. Thus basically this conference aims to deliberate the Asian and African countries from the colonialization of the North countries in the form of economic exploitation of Asian and African people.

\section{WTO as New Challenge}

Cold war has ended and the new trade regimes was born in 1995 after Uruguay Round, World Trade Organization (WTO) as successor to the General Agreement on Tariff in Trade (GATT) has born and became new multilateral trading system, and parts of world economic order. As new system, WTO run the spirit greater liberalization so there is no turning back if one of member has committed and liberalized one sector or member cannot de-liberalize their market access. 
There are several goods which regulated in WTO: goods, services and intellectual property with basic principles General Agreement on Trade in Service (GATS) which regulate trade in service issue, Trade Related Aspect of Intellectual Property Rights (TRIPS), General Agreement on Tariff in Trade (GATT) (WTO,2015). Other agreement such Trade Related Investment Measures (TRIMS) and Agreement On Agriculture (AOA) which cover investment regulation and agricultural products also became WTO engine to make fair trade in international context.

The idea of market access is one of important item in WTO, which succeed in attract other countries to join its membership. With member commitment in liberalizing their sector, any member can open their market and give their consumers a choice to choose a goods with an adequate price. However, although each member has committed to open their access by lowering its tariff or losing policy restriction but sometimes members do discrimination and create trade dispute between members.

To handle the issue, equipped with Dispute Settlement Body (DSB), WTO as new regime also offer an assurance for any trade dispute within its member in which member can retaliate another member if there was a discriminatory measures. To notes, this DSB presumably managed members keep in the right track from WTO principles, and preventing the members to distort international trade. Furthermore, WTO principles that becoming DSB to act is as follows: Trade without discrimination; Freer trade, gradually through negotiation; predictability through binding and transparency; Promoting fair competition; Encouraging development and economic reform (Bown and Ruta, 2008)

Along with its spirit, WTO had run several rounds to discussing an agreement, dispute of interest unavoidable emerged especially between developed and developing countries. New agreement concerning to international trade that binding another member such General Agreement on Trade in Service (GATS) once made both of side disputed. In this case, develop countries engined by established service sector tried to enter the developing countries market, while developing countries feared their competitive advantage will be stolen by service industry from develop country. Another issue such Trade Related Aspect of Intellectual Property 
Rights (TRIPS) also spring hot debate between those side due technology asymmetry in developing countries (Pugatch, 2014).

There are function and goals of WTO that seem generous to all of the member countries, but will be accessed further in the following analysis in this paper. First, this regime aims to regulate trade agreement among countries. It also boostsflow of international trade through its principle such as non-discrimination, gradually freer trade, predictable international trade since the regulations are stated clearly, promoting fair competition, and stimulate economic development. WTO also functions to settle the dispute in international trade. Further, it functions as the trade negotiation forum. Monitoring trade policy of member countries is also done by this regime. The last, it gives technical assistance to the developing countries (Hawin, 2013).

Although WTO share same vision, to established fair trade, however, practically the member which consisted on both developed and developing countries it is obvious each members have their own interest. Blocs based on each economic interest remains exist, and emerged along with issue which discussed in each WTO round, no wonder W'TO round last longer if the issue was sensitive.

Doha round has been an example on how WTO round were getting tough, it was the most difficult multilateral trade round ever launched. It is broader (more issues involved), deeper and sensitive due each blocs (G-33 and US, UK blocs) called agriculture issue was important in both sides (Grammling, 2007). While developed countries tried to convince each member to loosen its trade restriction, but at the same time they also give more subsidies to their agricultural product which mean developing countries will not able to bear the competition pressure. Yet, the round remains up to this present.

It is unavoidable, clashes of interest between developing and developed countries remains exist, developing countries still get unfair situation same as what history had told us. Looking back to Bandung Spirit that developing countries have, independence in economic can't be seen within WTO trading system. Two of WTO agreements below, trade liberalization on agriculture sector by AoA and intellectual property rights issue by TRIPs, will show us how global trade order create unfair situation for developing countries, where Bandung Spirit called for its relevancy. 


\section{Trade Liberalization on Agriculture Sector}

Today, agriculture remains the most distorted sector of the world economy. The Uruguay Round Agreement on Agriculture (AoA) took a major step forward by bringing the sector within the purview of the multilateral trading rules but its success in opening up the sector to global competition was at best limited. Therefore, agricultural liberalization is rightly the top priority in the Doha negotiations (Panagariya, 2009)

There remains considerable confusion, however, on who protects agriculture and how much, which countries stand to benefit from the liberalization most, and whether there are potential losers and if so what might be done about it. Because many of the potential exporters of agricultural products happen to be developing countries and many potential importers developed countries, liberalization in this area has an obvious North-South dimension.

Negotiations at the WTO pose tough political and economic challenges for the countries involved. The global chess game of trade negotiations reflects the more fundamental reality of how different economies are structured and how the world's population makes a living (Polaski, 2005). In rich countries, most people work in service industries of manufacturing. Very few make their living through agriculture. By contrast, in poor countries, agriculture is typically the largest employer. In lowincome countries, an average 68 percent of the population makes its living through farming. Even in middle-income countries, 25 percent of the population is engaged in agriculture. These very different pattern of employment between developed and developing countries explain the broad context for the decision by developing countries to insist that their concerns about agriculture must be satisfied before they will commit to concessions in manufacturing and service sectors in the trade talks.

When WTO's Agreement on Agriculture (AoA) was established in 1995 together with the WTO itself, it had been expected to reduce Northern subsidies and protection and benefit developing countries that were supposed to expand their exports significantly. However this expectation has not been fulfilled and instead there has been growing awareness of the imbalances and unfairness of the AoA itself. The flaws in the AoA enable developed countries to continue high levels of protection, whilst many developing countries have liberalized and their farmers are 
facing severe and often damaging competition, often from imports artificially cheapened through subsidies (Third World Network, 2006).

In the AoA, under the market access rules, all members had to abolish quantitative restrictions and non-tariff barriers and replace these with tariffs, and members have to reduce their tariff levels by 36 per cent over six years for developed countries, and by 24 per cent over 10 years for developing countries. LDCs do not have to reduce their tariffs, but cannot raise their bound rates. Under the AoA, developing countries have committed to a programme and schedule of liberalizing their agriculture sector, similar to developed countries, the only concession being slightly lower reduction rates and slightly longer time schedules. The LDCs do not have to reduce their tariffs or subsidies, but cannot raise them.

The AoA contains several types of imbalances that are favorable to developed countries and unfavorable to developing countries. The essence of the imbalances is the following: "The WTO Agreement on Agriculture has permitted the developed countries to increase their domestic subsidies (instead of reducing them), substantially continue with their export subsidies and provide special protection to their farmers in times of increased imports and diminished domestic prices. The developing countries, on the other hand, cannot use domestic subsidies beyond a de minimis level (except for very limited purposes), export subsidies and the special protection measures for their farmers. In essence, developed countries are allowed to continue with the distortion of agriculture trade to a substantial extent and even to enhance the distortion; whereas developing countries that had not been engaging in such distortion are not allowed the use of subsidies (except in a limited way) and special protection.

By such kind of agreement under WTO, the defensive concern for developing countries is grounded in the risk that large number of subsistence farmers and farm-workers will see their incomes plummet if their countries are forced to reduce agricultural tariffs covering the crops that they grow. This risk arises because producers in other countries may be able to produce the same corps more cheaply owing to economies of scale, greater mechanization, differences in input costs, a more favorable climate, or other advantages in addition to the impact of subsidies. Once developing countries cut their tariffs, the resulting lower cost of imports could 
reduce poor famers' already low incomes or drive them off the land together. In countries with large numbers of subsistence farmers, such as India or Kenya, it is unlikely that sufficient opportunities would be created in other sectors to absorb these displaced farmers, at least in the short and medium term. As a result, poverty levels would rise and the countries would be worse off. In terms of employment, it is often the case that the internationally competitive corps are land and capital intensive, not labor intensive. So, even if agricultural sector grows, total employment in agriculture may decline if trade liberalization allows cheaper imports of the corps that are grown by the more numerous poor farmers.

Some of the most widely used economic models show that many developing countries will actually lose from trade liberalization on agriculture sector. There are three reasons for this outcome (Weisbrot and Baker, 2002). First, some countries will be hurt by the elimination of quotas that now allow them to sell a fixed amount of exports at a price that exceeds the competitive market price. Second, trade liberalization changes the relative process of various goods, and some countries will find that their export prices fall relative to the price of imports. Third, some developing countries currently benefit from access to cheap, subsidized agricultural exports from the rich countries.

In standard trade models, the gains to the developing countries from removing their own barriers are much greater than the gains from increased access to the markets of rich countries. However, developing countries also incur substantial costs from opening their markets, which are often overlooked. First, developing countries incur substantial problems from reducing their trade barriers. In many developing countries, tariff revenue accounts for 10-20 percent of government revenue, and in some cases considerably more. If tariffs are reduced or eliminated, these countries will have to impose large increases in other taxes in order to keep their budgets in line. The distortionary effect of these tax increases, as well as the costs and problems associated with collecting taxes from other sources, are generally ignored in economic models that project gains from eliminating trade barriers. Second, the removal of trade barriers is also likely to lead to large disruptions in agriculture. In most developing countries, a large portion of the population is still tied to the agricultural sector. If barriers to agricultural imports are removed too 
quickly, it can lead to large-scale displacement of the rural population. Standard economic models implicitly assume that these people are re-employed in other sectors of the economy, but rapid import liberalization can lead to substantial unemployment and underemployment, as well as dangerous levels of social and economic instability.

\section{Intellectual Property Rights Issue}

Trade Related to Intellectual Property Rights (TRIPs) was adopted on April 15, 1994 at Marrakesh after eight years negotiation since the issues of intellectual property rights firstly emerged in the system of General Agreement on Tariffs and Trade (GATT) in Uruguay Round in 1986. The talks in Uruguay Round were going to extend the trading system into several new areas, notably trade in services and intellectual property, and to reform trade in the sensitive sectors of agriculture and textiles. All the original GATT articles were up for review (World Trade Organization, 2015). TRIPs finally entry into force on January 1, 1995 when the system of GATT transformed into World Trade Organization (WTO) as the official trade order institution which has binding power to its members and several other functions.

Intellectual property rights (IPRs) was included into the mechanism of global trade order with the consideration that ideas and knowledge are important in trade activities since they can be commercialized. This issue was proposed by the developed countries in GATT (United States and West European countries) in Uruguay Round because they have various inventions related to the IPRs. It will be such loss for them if IPRs mechanism in trade is not ruled by the certain global trade order. The businessmen and companies in the developed countries have done various researches to invent various inventions that can be applied into their products and then distributed across the world in trade activities. Such researches need both long time and great amount of fund. Therefore, if those inventions, which were the result of long time with great fund, easily be copied without any regulation by other companies, it will hurt the inventor institutions which did great effort to find the invention. 
There were some contra arguments when TRIPs issue brought into the global trade order. It is because there is already an institution under the United Nations which concern in IPRs field, World Intellectual Property Organization (WIPO). Those who rejected the IPRs to be integrated into WTO thought that IPRs should be the issue that was discussed in the WIPO not in the WTO. However, in this case, WIPO does not have the forcing power for the application of the agreement in the national level, so there is no obligation for the member countries to adopt WIPO agreement into their national legislation. That is why those who have great interest in the field of TRIPs rally need to include TRIPs into global trade order and need clear regulation related to this.

By the integration of TRIPs into WTO, consequently it gets the same treatment and regulation as the other agreement (GATT and GATS), such as most non-discrimination and most-favored nation. WTO also becomes the dispute settlement body in the dispute cases related to TRIPs. In Uruguay Round, there are five agreements in TRIPs: Basic principles of trade system and agreement in IPRs issues, proper protection toward IPRs, law enforcement in IPRs issues, dispute settlement, and special transitional arrangement. TRIPs involve the protection of Copyrights, Patent, trademark (including service mark), Geographic Indication, Industrial Design, integrated Circuits Layout Design, Undisclosed Information and Trade Secrets.

After its entry into force, TRIPs agreement implemented by the developed countries which have well established IPRs system already while gave the extension time of application to the developing countries and least developed countries. As TRIPs agreement brought the interest of mostly actor in the developed countries, there are various problems in the implementation, especially related to the interest of developing countries. We can see the problem from the perspective of prosperity and human life.

To begin with the prosperity, since IPRs mostly owned by actors from developed countries, for example big multi-national corporations, which have done various research to find invention for their products, the wealth got from the global trade with IPRs protection mostly flow to the developed countries. This situation also leads to the domination or monopoly the invention, where developed countries 
dominate certain product and invention for their business activities. Developing countries consequently just are the loyal consumer for those inventions. Even, they have to spend a large amount of money to access those inventions and products.

In addition, bio piracy is another issue related to the wealth perspective in TRIPs. Developing countries have various kinds of natural resources. Unfortunately, they mostly do not aware yet about the mechanism of TRIPs that actors from developed countries do research to find out the potency of those natural resources and apply patent for them. Consequently, developing countries where those natural resources origin not only lost the possibility to get the benefit like if they are the owner of the IPRs but they also prohibited to use their own natural resources in commercial.

Move to the human life related to TRIPs agreement, TRIPs agreement affect the health and the life of human being in the region across the globe. We can see from the case when HIV/AIDS epidemic affects many developing countries acutely (UNAIDS, 2000), and where much of the infected population is said to be unable to obtain effective therapies because of their prohibitive cost. The annual cost of advanced retroviral therapies in South Africa, where one in eight persons are thought to be infected, is said to be about (U.S.) $\$ 12,000$, far beyond the means of most South Africans. Only about $5 \%$ of the 1 million citizens of Thailand believed to be infected are able to afford the AIDS therapies prescribed to them.

Much of the problem is attributed to the prices charged by pharmaceutical companies for their patented medications. A United Nations study reports, for example, that $150 \mathrm{Mg}$ of the HIV drug flucanazole costs $\$ 55$ (U.S.) in India, where the drug does not enjoy patent protection, as compared to $\$ 697$ in the Philippines, $\$ 703$ in Indonesia and $\$ 817$ in the Philippines, where the drug is patented. Similarly, the HIV treatment known as AZT costs $\$ 48$ per month in India, as compared to $\$ 239$ in the United States where patent protection exists (UNCHR,2001).

Developing nations where patents are in place seek to reduce those prices with measures that the pharmaceutical manufacturers say would infringe their intellectual property rights. Some of these initiatives have already brought forth legal challenges. South Africa was the target of litigation initiated by a number of pharmaceutical manufacturers over South Africa's Medicines and Related Substances 
Control Act of 1997 (Nash, 2000). The United States government also initiated action against Brazil within the World Trade Organization (WTO) over the compulsory licensing provisions in Brazil's Industrial Property Law. Developing nations subsequently united in an effort to relax (or at least clarify) the scope of intellectual property protection required for pharmaceuticals under the WTO Agreement on Trade-Related Aspects of Intellectual Property Rights (TRIPs). Certain developed nations, most prominently the United States and Switzerland, responded with a campaign to protect their interpretation of TRIPs against any developments that might undermine it.

The eventual result was a ministerial interpretation of the TRIPs agreement in the form of a Declaration on the TRIPs Agreement and Public Health, one of the few concrete legal developments during the recent WTO ministerial meetings in Doha, Qatar. The declaration gives the developing nations many of the legal clarifications that they were seeking, although a number of issues remain unresolved. The precise impact of the Doha declaration on the policies of developing nations remains to be seen, but it seems likely that the declaration will embolden them to enact measures that will reduce the returns to pharmaceutical patent holders, at least with respect to drugs that are used to treat certain diseases. Such measures will likely include the award of compulsory licenses for the production of patented medications (with minimal royalties payable to the patent holder), and the allowance of parallel imports of medications from nations where prices are lower.

\section{Bandung Spirit in the Global Trade Order}

Globalization is often taken to mean a process that is synonymous with liberalization, or the opening up of the local and national markets to the global market. However, the economic globalization process is much more nuanced than this simple or automatic linkage between globalization and liberalization. Whilst there has been very significant liberalization in recent years, this has been accompanied by the continuation or even the accentuation of protectionism in some areas and in some countries, including some major developed countries. For example, the high subsidization of and high tariffs on agricultural products constitutes the continuation of high protection of the agriculture sector in the rich countries. Also, the 
internationalization of intellectual property rights (IPR) systems through the WTO may erode the rights of farmers and holders of traditional knowledge. Thus, the implementation of trade liberalization on agriculture sector by AoA agreement and intellectual property rights issue by TRIPs agreement, are our main discussion about the relevance of Bandung Spirits in the context of global trade order. Bandung spirit itself originally founded to accommodate the interest of Asia and Africa countries which just got their independent among the domination of great power and colonization. In the global trade context, Bandung Spirit Values emphasize on the interest of developing countries among the domination of global trade regime's regulations (WTO) which have less benefit to them or even give disadvantage.

The most important aspect of globalization is the globalization of policy making. Policies and decisions on a range of issues that were once under the sole or main purview of national governments are now made through international agencies or under their influence. Many developing countries are "policy takers" in the sense that they have had little say in the making of the rules or policies of some of the powerful international agencies, particularly WTO, and they have to implement the policies at national level which have been laid out through these agencies. The developed countries are able to be "policy makers" as they have overwhelming influence at the WTO. This shift of power to institutions that are dominated by the developed countries has meant the reduction of the influence of the developing countries in decision-making over economic issues at the international level.

There have been increasing concerns that the policies adopted at or by WTO have not been appropriate or effective in meeting the development needs of developing countries. In the area of trade and trade-related rules, the concerns have particularly centered on the disappointment by developing countries that they have not benefited much in trade or income terms from the implementation of WTO rules and some of them have suffered cost and losses. For many developing countries, the potential benefits of meeting export opportunities have not been realized, whilst the risks of import liberalization have become very real and have already adversely affected rural livelihoods and national incomes. Relating to the Bandung Conference, it potentially lead to the new shape of colonialization, such as 
economic control, intellectual control, and actual physical control by a small and alien community within a nation.

Thus the policies associated with the global trade order are a strange combination of liberalization and protectionism. The strangeness is perhaps accentuated by the fact that in some important instances developing countries are asked to undertake more intensive liberalization, whilst the developed countries are proposing to retain or even increase protectionist policies. The structural adjustment policies have had a major impact on agricultural policies in developing countries. The policies normally include the following approaches and measures as they pertain to the rural sectors: the withdrawal of the state from economic activities, the closure or downgrading of state marketing boards, privatization, reduction or removal of subsidies, elimination of import controls such as quantitative restrictions, reduction of import tariffs, re-orientation towards exports, and investment liberalization and deregulation, or the opening up to foreign ownership of assets. In particular, the removal of subsidies and protection from imports have made the rural producers more vulnerable to the direct effects and vagaries of the global markets, as the interventionist measures and capacity of the state were withdrawn or withheld. In many countries, rural producers are facing intense competition from imports that are cheaper than their own produce.

Being the WTO member, the developing country governments were hopeful that they would benefit from the new rules in agriculture, as the incorporation of agriculture into the system of the WTO would presumably lead to the dismantling of protection in the developed countries. Agriculture is one area where the developing countries are widely believed to have a comparative advantage, and thus they expected to benefit from expanded exports to the rich markets. However, they were sorely disappointed, as the expected benefits have not accrued, due to continued protectionism in the North. This maintenance of protectionist measures was moreover allowed within the framework of the AoA. On the other hand, the developing had, under the AoA, also committed to place strict limits on their domestic subsidies, to give up quantitative restrictions placed on imports, and to reduce their bound tariffs. These commitments made it even more difficult for the developing countries to promote and protect the interest of their rural producers. 
The global economic framework on agriculture, shaped to a large extent by the rules of the WTO, have resulted in a situation where the developed countries are able to continue with and even expand their domestic subsidies, and to continue with significant levels of export subsidies, as well as high tariffs on their sensitive agriculture products, whilst the developing countries are constrained by the rules of the W'TO from increasing their farm subsidies, and have strong pressures to maintain low applied tariff rates and even reduce these, as well as to significantly reduce their bound tariffs through existing WTO rules and new proposed rules. The imbalances in the global framework have handicapped the developing countries, which already have weak starting points due to their lack of financial and technical resources and their low level of development. The unilateral policies taken under structural adjustment have then been reinforced or complemented by multilateral commitments that the countries are obliged to implement under the WTO rules. This combination of policies initiated under loan conditionality and then reinforced under multilateral rules have bound the developing countries in a web of commitments and policy constraints and measures and they find it difficult within this context to maneuver or to be able to choose between policy options those that are suitable for their agriculture development. From this view, Bandung Spirit, symbolized by independence in policy, does no longer exist within trade liberalization on agriculture sector.

TRIPs also provide a good reference to analyse the relevance of Bandung Spirit Values in the global trade regime which dominates global trade in this century. Concerning the integration of IPRs into WTO, we can use Hegemonic Stability Theory (HST) to analyse that integration. HST argues that a hegemon - a leading power able to shape outcomes - is needed if international economic cooperation is to succeed (Bayne, 2013). Without a coercive power, of a hegemon it would not be possible to ensure effective compliance with any regimes that were established. The theory can also envisage a benign hegemon, that is not concerned about relative power gains, so that others may benefit more from the economic order than the hegemon responsible for providing it.

In this case, we can see the United States as the leading power or the hegemon in the WTO. This state can bring the issue of IPRs into the WTO. TRIPs 
gives more benefit to the interest of the United States than the developing countries since invention and technology related to IPRs mostly owned by the actors from United States and the other developed countries instead of from developing countries and least developed countries. However, finally developing countries and least developed countries accepted this issue to integrate into the WTO after several negotiations after Uruguay Round. Here, the value of independence to take the policy of the developing country from Bandung Spirit seems not relevant since the integration IPRs into WTO more benefit developed countries instead of developing countries for instance in the context of benefit in income from global trade.

In the context of global trade regime, it can be interpreted as the accommodation the interest of developing countries in the regime and how it deals with the interest of the developed countries. In the case of global health, we can see from the perspective of independence in policy and solidarity value of Bandung Spirit. From the case where the emergence of epidemic diseases in developing countries, we can see how the alliance of developing countries struggle for the access the medicine protected by TRIPs mechanism while they are needed to fight epidemic but inaccessible due to the high price of those medicines. This effort got the opposition by developed countries as the producers of the protected medicine. However, finally in the Doha Development Agenda, the interest of the developing countries to access medicine was accommodated. From their effort, finally developing countries can access medicine to fight several epidemic diseases.

From this case, we can see how TRIPs agreement affects the independence of developing counties in taking policy to get the equal benefit with the developed countries. Even, in some cases, such as in bio piracy and the access of expensive medicine to fight epidemic diseases, developing countries suffer from this agreement. However, in the struggle of developing countries in Doha Round where finally they will get access to the medicine for epidemic diseases, reflect the other side of Bandung Spirit value, it is solidarity. It was showed from how the alliance of developing countries struggle to reach the interest in the access of medicine protected by TRIPs agreement to solve epidemic problem in developing countries. 


\section{References}

Bayne, Nicholas, and Stephen Woolcock. 2013.The New Economic Diplomacy. (nd): 23

Bown, Chad P., and Michele Ruta. 2008. "The Economics of Permissible WTO Retaliation”. 21 2015. <https://www.wto.org/english/res_e/reser_e/ersd200804_e.pdf>

Grammling, Stefen. 2007.Trade Liberalization and Development -WTO and the Doha Round. Swiss.

Hawin, Muhammad. 2013.Hand Book of International Trade Law, Global Trade Diplomacy, Gadjah Mada University

International Centre for Trade and Sustainable Development, U.S. Drops TRIPs

Dispute Against Brazil's Patent Law, Bridges Between Trade and Sustainable Development

Kementerian Luar Negeri Republik Indonesia. Sekilas WTO, seventh edition. (nd):

Marsudi, Retno LP, The Jakarta Post, Insight: The Bandung Spirit in Today's World, taken from

<http://www.thejakartapost.com/news/2015/04/15/insight-the-

bandung-spirit-today-s-world.html>

Nash, Duane. 2000.South Africa's Medicines and Related Substances Control Amendment Act of 1997, 15 Berkeley Tech. L. J.

Nasudarai Helen, E.S. Bandung and The Political Economy of North-South Relations: Sowing The Seeds for Revisioning International Society.Institute of Defense and Strategic Studies Singapore

Panagariya, Arvind.2005. "Agricultural Liberalization and the Least Developed Countries”. World Economy: Global Trade Policy.

Polaski, Sandra.2005. "Agricultural Negotiations at the WTO: First, Do No Harm". Trade, Equity, and Development.

Pugatch, Meir Perez.2004.The International Political Economy of Intellectual Property Rights. USA.

Third World Network. 2006. "Globalization, Liberalization and Protectionism: Impacts on Poor Rural Producers in Developing Countries”. 21 ${ }^{\text {st }}$, March, 
2015.

http://www.ruralpovertyportal.org/documents/654016/100542/DLFE1614.pdf

UNAIDS. 2000. "The Global HIV/AIDS Epidemic, 281 J. Am. Med, UNAIDSWHO, Aids Epidemic Update”. 25 ${ }^{\text {th }}$, March, 2015. $<$ www.unaids.org/waq/2000/wad00/files/wad epidemic report.htm $>$ Alan O. Sykes. TRIPs, Pharmaceuticals, Developing Countries, and the Doha "Solution". (nd)

United Nations Commission on Human Rights, Report of the High Commissioner. The Impact of the Agreement on Trade-Related Aspects of Intellectual property Rights on Human Rights 44, E/CN.4/Sub.2/2001/13

Weisbrot, Mark, and Dean Baker. 2002. "The Relative Impact of Trade Liberalization on Developing Countries”. 21 2015. <http://www.cepr.net/documents/publications/trade_2002_06_12.pdf $>$

World Trade Organization. (nd). "The Uruguay Round". 25 ${ }^{\text {th }}$ March, 2015. <https://www.wto.org/english/thewto_e/whatis_e/tif_e/fact5_e.htm>

World Trade Organization. (nd). "Understanding the WTO: the Agreements". 21 $1^{\text {st }}$, March, 2015.

<www.wto.org/english/thewto_e/whatis_e/tif_e/agrm1_e.htm>

World Trade Organization. (nd). "Understanding the WTO: Basics". 21 $1^{\text {st }}$, March, 2015.

<https://www.wto.org/english/thewto_e/whatis_e/tif_e/fact2_e.htm> Yan, Zang, The Mississippi Quarterly Report, 1997, in Yosef Purnama, The Spirit of Bandung, taken from <http://yaleglobal.yale.edu/content/spiritbandung >, accessed on May 4th,2016 